\title{
HUBUNGAN TINGKAT PENDIDIKAN ORANG TUA DENGAN PENGETAHUAN TENTANG KEKERASAN SEKSUAL PADA ANAK USIA PRASEKOLAH DI TK AISYIYAH KHADIJAH BANGUNJIWO TIMUR KASIHAN BANTUL
}

\author{
Desi Asih Purnamasari ${ }^{1 凶}$, Esitra Herfanda ${ }^{2}$ \\ 1-2 Jurusan Kebidanan, Universitas ‘Aisyiyah Yogyakarta, Indonesia \\ esitra.herfanda@gmail.com, Tlp: +2856432340006
}

Genesis Naskah:

Diterima 14 November 2018; Disetujui 10 Desember 2018; Di Publikasi 1 Februari 2019

\begin{abstract}
Abstrak
Kekerasan seksual setiap tahun mengalami peningkatan, korbannya bukan hanya dari kalangan dewasa saja sekarang sudah ke anak-anak bahkan balita. Jumlah laporan kasus kekerasan pada anak di Indonesia pada tahun 2014 sebanyak 2.737 kasus dengan 52\% kasus kekerasan seksual. Unit Perlindungan Perempuan dan Anak (PPA) Polres Bantul mencatat, ada sebanyak 24 anak yang menjadi korban kejahatan seksual sepanjang 2015 hingga pertengahan 2017. Dari total 24 kasus kejahatan yang dilaporkan ke aparat hukum, kasus paling banyak terjadi pada 2015 sebanyak 12 kejadian, 2016 sebanyak delapan kasus dan periode hingga Oktober 2017 sebanyak empat kasus. Penelitian ini bertujuan diketahuinya Hubungan Tingkat Pendidikan Orang Tua Dengan Pengetahuan Tentang Kekerasan Seksual Pada Anak Usia Prasekolah Di TK Aisyiyah Khadijah Bangunjiwo Timur. Jenis penelitian yang digunakan dalam penelitian ini adalah penelitian kuantitatif dengan metode korelasional. Pengambilan sampel diambil dengan teknik simple random sampling dan dihitung dengan rumus slovin sehingga diperoleh sampel sebanyak 84 orang. Hasil uji statistik menggunakan kendal tau diperoleh nilai p-value $<0,05$ yang berarti ada hubungan antara tingkat pendidikan orang tua dengan pengetahuan tentang kekerasan seksual pada anak usia prasekolah di TK Aisyiyah Khadijah Bangunjiwo Timur. Respoden diharapkan dapat lebih peduli dan giat dalam mencari informasi tentang kekerasan seksual pada anak, khususnya tahap awal pendidikan seks.
\end{abstract}

Kata Kunci : Pengetahuan tentang Kekerasan Seksual, Tingkat Pendidikan

\section{THE RELATIONSHIP BETWEEN PARENT'S EDUCATION AND KNOWLEDGE ABOUT SEXUAL VIOLENCE IN PRESCHOOL CHILDREN AT AISYIYAH KHADIJAH KINDERGARTEN OF BANGUNJIWO TIMUR KASIHAN BANTUL}

\begin{abstract}
Sexual violence increases every year. The victims are not only from adults but also even children. The number of reports about violence cases in children in Indonesia during 2014 reached 2,737 cases with 52\% of cases of sexual violence. Women and Child Protection Unit of Bantul Police Office noted that there were as many as 24 children became the victims of sexual crimes throughout 2015 to mid-2017. Out of a total of 24 reported crime cases, the most cases occurred in 2015 as many as 12 incidents, 2016 as many as eight cases and the period up to October 2017 as many as four cases. This study aims to find out the relationship between parent's education level and knowledge about sexual violence in preschool children at Aisyiyah Khadijah Kindergarten of Bangunjiwo Timur. The type of research used quantitative research with correlational methods. Sampling was taken by simple random sampling technique and calculated by Slovin formula. The samples were as many as 84
\end{abstract}


people. The results of statistical tests using kendal tau obtained p-value $<0.05$, which means that there was a relationship between parent's education level and knowledge of sexual violence in preschool children at Aisyiyah Khadijah Kindergarten of Bangunjiwo Timur. Respondents are expected to be active in seeking information about sexual violence in children, especially the early stages of sex education.

\section{Keywords: Knowledge of Sexual Violence, Level of Education}

\section{Pendahuluan}

Anak usia prasekolah merupakan masa emas seseorang dalam kehidupan. Di masa emas tersebut, seseorang mengalami masa perkembangan otak yang paling optimal, ia memiliki memori otak yang kuat dalam mengingat sesuatu. Sehingga anak dalam usia 0-5 tahun perlu perhatian dan dijaga agar pertumbuhan dan perkembangannya (WHO, 2014).

Di Indonesia kejadian kasus kekerasan pada anak semakin meningkat terutama pada kasus kekerasan seksual anak. Pada tahun 2013 terdapat 2.676 kasus, 2014 mengalami peningkatan sebanyak 2.737 kasus dan pada 2015 terdapat 2.898 kasus (KPA, 2016). Berdasarkan kajian data Dinas Sosial, P3A Bantul secara rinci mencatat Kasus Kekerasan Pada Anak Tahun 2015 sebanyak 14 kasus, 2016 mengalami peningkatan sebanyak 70 kasus, dan pada tahun 2017 sebanyak 59 kasus (KPA, 2016).

Kekerasan seksual terhadap anak menurut ECPAT merupakan hubungan atau interaksi antara seorang anak dengan seorang yang lebih tua atau orang dewasa seperti orang asing, saudara kandung atau orang tua dimana anak dipergunakan sebagai objek pemuas kebutuhan seksual pelaku (Sari, 2009). Kekerasan seksual yang terjadi pada anak dapat menimbulkan dampak traumatis pada korbannya, baik secara fisik maupun secara emosional yang nantinya menimbulkan gangguan-gangguan secara psikilogis.

Upaya pemerintah untuk menghindari terjadinya kejahatan terhadap anak, khususnya kekerasan seksual telah dibentuk Undang-Undang Nomor 35 Tahun 2014 Pasal 20 tentang Perlindungan Anak tentang Perlindungan Anak menitik beratkan serta memberikan kewajiban dan tanggung jawab kepada Negara, Pemerintah, Pemerintah Daerah, Masyarakat, Keluarga dan Orang Tua atau Wali dalam penyelenggaraan perlindungan anak. Pemerintah dalam hal ini mempertegas perlunya pemberatan sanksi pidana dan denda bagi pelaku kejahatan terhadap anak terutama kepada kejahatan seksual yang bertujuan untuk memberikan efek jera, serta mendorong adanya langkah konkrit untuk memulihkan kembali fisik, psikis dan sosial anak.

Orangtua memiliki peran penting dalam memberikan informasi, arahan, dan pemahaman tentang seksualitas pada anak secara benar. Sering kali orang tua masih sungkan berbicara tentang hal yang berkaitan dengan seksualitas kepada anak-anaknya, menganggap hal itu tabu, dan belum perlu diberikan kepada anak-anak sejak dini. Orang tua berharap anak akan paham sendiri sejalan dengan bertambahnya usia mereka.

Tujuan dari penelitian ini yaitu diketahuinya hubungan antara tingkat pendidikan orang tua dengan pengetahuan tentang kekerasan seksual pada anak usia prasekolah di TK Aisyiyah Khadijah Bangunjiwo Timur.

\section{Metode}

Penelitian yang dilakukan merupakan penelitian kuantitatif dengan metode korelasional yaitu penelitian untuk mencari hubungan antara dua variabel. Pendekatan yang digunakan adalah dengan metode cross sectional yaitu pendekatan yang menekankan waku pengukuran data hanya satu kali waktu (Notoatmodjo, 2012). Populasi dalam penelitiann ini adalah orang tua yang memiliki anak usia prasekolah (3-6 tahun) di TK Aisyiyah Khadijah Bangunjiwo Timur yang berjumlah 137 orang tua. Teknik pengambilan sampel menggunakan simple random sampling dengan rumus slovin. didapatkan sampel sebanyak 81 orang dan untuk mengantisipasi drop out. Penelian ini menggunakan alat pengumpulan 
data berupa kuesioner yang berkaitan dengan sebanyak 25 pertanyaan. peneliti mengambil sampel pengetahuan orang tua tentang kekerasan seksual pada sebanyak 84 orang.

anak usia prasekolah dengan jumlah pertanyaan

Hasil Penelitian dan Pembahasan

Tabel 1 Distribusi Frekuensi Umur Orang Tua

\begin{tabular}{|c|c|c|}
\hline Karakteristik & Frekuensi (n) & Presentase $(\%)$ \\
\hline \multicolumn{3}{|l|}{ Umur } \\
\hline $17-25$ tahun & 4 & 4,8 \\
\hline $26-35$ tahun & 49 & 58,3 \\
\hline$>30$ tahun & 31 & 36,9 \\
\hline \multicolumn{3}{|l|}{ Pendidikan } \\
\hline Pendidikan Dasar & 22 & 26,6 \\
\hline Pendidikan Menengah & 46 & 54,8 \\
\hline Pendidikan Tinggi & 16 & 19 \\
\hline \multicolumn{3}{|l|}{ Agama } \\
\hline Islam & 84 & 100 \\
\hline \multicolumn{3}{|l|}{ Jumlah anak } \\
\hline 1 anak & 30 & 35,7 \\
\hline$>1$ anak & 54 & 64,3 \\
\hline \multicolumn{3}{|l|}{ Penghasilan } \\
\hline$<\mathrm{UMR}$ & 42 & 50 \\
\hline > UMR & 42 & 50 \\
\hline Total & 84 & 100 \\
\hline
\end{tabular}

Berdasarkan tabel 1 dapat diketahui bahwa responden dalam penelitian ini sebagian besar berumur 26-35 tahun, yakni sebanyak 49 (58,3\%) orang tua. Seluruh responden beragama islam yaitu 84 (100\%) dengan jumlah anak lebih dari satu anak yaitu sebanyak $54(64,3 \%)$ dan jumlah orang tua yang hanya memiliki satu anak sebanyak 30 (35,7\%). Sedangkan pendidikan responden paling banyak di pendidikan menengah sebanyak 46 $(54,8 \%)$. UMR responden > UMR sebanyak 42(50\%) sedangkan responden yang memiliki penghasilan < UMR sebanyak $42(50 \%)$.

Tabel 2 Pendidikan Umur Orang Tua

\begin{tabular}{clcc} 
No & Karakteristik & Frekuensi (n) & Presentase (\%) \\
\hline 1. & Pendidikan Dasar & 22 & 26,6 \\
2. & Pendidikan Menengah & 46 & 54,8 \\
3. & Pendidikan Tinggi & 16 & 19 \\
& Total & 84 & 100 \\
\hline
\end{tabular}


Berdasarkan tabel 2 dapat diketahui bahwa, tingkat pendidikan orang tua terbanyak (54,8\%) atau 46 orang tua adalah tingkat pendidikan menengah.

Tabel 3 Tingkat Pengetahuan Responden

\begin{tabular}{clcc}
\hline No & Tingkat Pengetahuan & Frekuensi (n) & Presentase (\%) \\
\hline 1. & Kurang & 33 & 39,3 \\
2. & Cukup & 23 & 27,4 \\
3. & Baik & 28 & 33,3 \\
& Total & 84 & 100 \\
\hline
\end{tabular}

Berdasarkan tabel 3 dapat diketahui bahwa $33(39,3)$ orang tua memiliki tingkat pengetahuan tentang kekerasan seksual pada anak usia prasekolah kurang, kemudian 23 (27,4\%) orang tua memiliki tingkat pengetahuan tentang kekerasan seksual ada anak usia prasekolah cukup dan 28 (33,3\%) orang tua dengan tingkat pengetahuan baik tentang kekerasan seksual pada anak usia pra sekolah.

\begin{tabular}{|c|c|c|c|c|c|c|c|}
\hline \multirow{2}{*}{\multicolumn{2}{|c|}{ Variabel yang diteliti }} & \multicolumn{4}{|c|}{$\begin{array}{l}\text { Tingkat Pengetahuan Orang Tua tentang Pencegahan } \\
\text { Kekerasan Seksual Pada Anak Usia Prasekolah }\end{array}$} & \multirow[t]{2}{*}{$p$ value } & \multirow[t]{2}{*}{$\begin{array}{c}\text { Koef. } \\
\text { Kontingensi }\end{array}$} \\
\hline & & Kurang & Cukup & Baik & Total & & \\
\hline $\begin{array}{l}\text { Ting } \\
\text { kat }\end{array}$ & Dasar & $21(25,0 \%)$ & $0(0 \%)$ & $\begin{array}{l}1 \\
(1,2 \%)\end{array}$ & $22(26,2 \%)$ & 0,000 & 0,69 \\
\hline $\begin{array}{l}\text { Pen } \\
\text { didi }\end{array}$ & Menengah & $12(14,3 \%)$ & $22(26,2 \%)$ & $\begin{array}{l}12 \\
(14,3 \%)\end{array}$ & $46(54,8 \%)$ & & \\
\hline kan & Tinggi & $0(0 \%)$ & $1(1,2 \%)$ & $\begin{array}{l}15 \\
(17,9 \%)\end{array}$ & $16(19,0 \%)$ & & \\
\hline & Total & $33(39,3 \%)$ & $23(27,4 \%)$ & $\begin{array}{l}28 \\
(33,3 \%) \\
\end{array}$ & $84(100 \%)$ & & \\
\hline
\end{tabular}

Berdasarkan tabel 4 maka didapatkan simpulan bahwa sebanyak 22 orang tua dengan latar belakang tingkat pendidikan dasar memiliki keragaman tingkat pengetahuan dengan persebaran 21 orang tua dengan tingkat pengetahuan kurang, tidak ada yang memiliki pengetahuan cukup dan terdapat 1 orang tua yang memiliki tingkat pengetahuan baik.

Selanjutnya, sebanyak 46 orang tua dengan latar belakang tingkat pendidikan menengah memiliki keragaman tingkat pengetahuan dengan persebaran 12 orang tua dengan tingkat pengetahuan kurang, 22 orang tua dengan tingkat pengetahaun cukup dan 12 orang tua dengan tingkat pengetahuan baik.

Kemudian, sejumlah 16 orang tua dengan latar belakang pendidikan tinggi memiliki keragaman tingkat pengetahuan dengan persebaran 1 orang tua dengan tingkat pengetahuan kurang, tidak ada orang tua dengan tingkat pengetahuan cukup, dan 15 orang tua dengan tigkat pengetahuan tinggi.

Tujuan penelitian ini untuk mengetahui hubungan tingkat pendidikan orang tua dengan pengetahuan tentang kekerasa seksual pada anak usia prasekolah. Berdasarkan uji Kendal Tau yang dilakukan peneliti didapatkan nilai $p$ value sebesar 0,000 dan nilai koefisiensi kontingensi sebesar 0,690. Hasil uji ini didapatkan kesimpulan bahwa $\mathrm{H}_{\mathrm{a}}$ diterima dan $\mathrm{H}_{0}$ ditolak yang berarti terdapat hubungan antara tingkat pendidikan orang tua dengan pengetahuan tentang kekerasan seksual pada anak usia prasekolah dan tingkat kekuatan antara dua variabel dalam penelitian tinggi. 
Berdasarkan hasil penelitian, didapatkan karakteristik pendidikan orang tua terbanyak yakni tingkat pendidikan menengah sebanyak 46 orang $(54,8 \%)$ dengan didominasi dengan tingkat pengetahuan cukup.

Pendidikan adalah suatu usaha menanamkan pengertian dan tujuan agar oada diri manusia (masyarakat) tumbuh pengertian, sikap dan perbuatan positif. Pada dasarnya usaha pendidikan adalah perubahan sikap dan perilaku pada diri manusia menuju arah positif dengan mengurangi faktor-faktor perilaku dan sosial budaya negatif (Notoatmodjo, 2012).

Dengan semakin tingginya tingkat pendidikan maka akan semakin menentukan luas pengetahuan yang dimiliki oleh responden serta semakin mudah dan cepat pula untuk menerima berbagai informasi dari berbagai media khususnya tentang kekerasan seksual pada anak usia prasekolah. Hal ini sejalan dengan penelitian yang dilakukan oleh Widyawati (2016) yang menyatakan bahwa tingkat pendidikan seseorang mempengaruhi kecerdasan dan tingkat pengetahuan serta pemahaman seseorang terhadap suatu pembahasan. Semakin tinggi pendidikan seseorang semakin tinggi pula kecerdasan dan tingkat pemahaman seseorang.

Berdasarkan hasil penelitian didapatkan orang tua dengan tingkat pengetahuan kurang sebanyak $33(39,3 \%)$, kemudian tingkat pengetahuan cukup sebanyak $23(27,4 \%)$ dan orang tua dengan tingkat pengetahuan tinggi sebanyak 28 $(33,3 \%)$.

Selanjutnya peneliti hubungkan karakteristik umur rata-rata responden, yakni $49(58,3)$ orang tua. Pada responden dengan kelompok umur 26-35 tahun sebagian besar berada pada tingkat pengetahuan kurang. Hal ini menunjukkan hasil penelitian tidak sesuai dengen teori menurut Potter dan Perry (2009) yang menjelaskan bahwa tugas perkembangan individu pada dewasa awal yang berada pada rentang usia 26-35 tahun yaitu mulai bekerja, memilih pasangan, mulai membina keluarga, mengasuh anak, mengelola rumah tangga, mengambil tanggung jawab sebagai warga negara dan mencari kelompok sosial yang menyenangkan. Bertambahnya umur seiring dengan bertambahnya pengalaman-pengalaman yang diperoleh orang tua dari berbagai sumber yang ada dan akan mempengaruhi pengetahuannya. Seseorang dalam rentang usia 25-35 tahun lebih berperan aktif dalam masyarakat dan kehidupan sosialnya yang mempengaruhi penerimaan informasi sehingga dapat meningkatkan pengetahuan orang tua tentang kekerasan pada anak.

Berdasarkan hasil penelitian juga di dapatkan bahwa sebagian besar orang tua dengan tingkat penghasilan < UMR memiliki tingkat pengetahuan kurang yaitu sebanyak 21 (25\%). Notoatmodjo (2012) menyebutkan faktor-faktor yang mempengaruhi pengetahuan seseorang adalah pendidikan, usia, sosial ekonomi dan pekerjaan. Pendapatan masyarakat sangat berpengaruh terhadap kemampuan masyarakat dalam membeli fasilitas-fasilitas sumber informasi untuk menunjang pengetahuan. Pekerjaan dan tingkat pendapatan sangat mempengaruhi seseorang dalam memperoleh informasi, baik informasi yang diperolah dari media buku maupun media lainnya. Semakin tinggi status pekerjaan dan tingkat pendapatan seseorang akan lebih mudah dalam memperoleh informasi baik dari orang lain maupun media massa. Tingkat sosial ekonomi seseorang menentukan tersediaya suatu fasilitas yang diperlukan untuk kegiatan tertentu, sehingga status ekonomi akan mempengaruhi pengetahuan seseorang. 
Hal ini dapat terjadi karena dimasyarakat orang tua bersikap apatis dan tidak berperan aktif memberikan pendidikan seks sejak dini kepada anak. Orang tua beranggapan bahwa pendidikan seks akan diperoleh anak seiring berjalannya usia ketika anak sudah dewasa nanti. Kurangnya pengetahuan orang tua terhadap kepentingan anak dalam menghadapi zaman yang semakin modern menjadi faktor utama belum terlaksananya pendidikan seks sejak dini di lingkup keluarga (Andika,2010).

Pendidikan seks harus mulai diberikan orang tua sejak dini dan bertahap sesuai degan perkembangan anak. Bila hal ini dilakukan saat beranjak dewasa, mereka tidak akan mencari penjelasan dari lingkungan sekitar yang terkadang menyesatkan. Membimbing dan melindungi anak, orang tua harus dibekali dengan pengetahuan yang memadai tentang kasus-kasus kekerasan seksual. Pengetahuan orang tua meliputi pengertian, jenis, tanda gejala dan cara mmencegah kekerasan seksual pada anak. Orang tua juga perlu megetahui siapa yang berpotensi menjadi pelaku dan anak yang berpotensi menjadi korban. Orang tua wajib memiliki pengetahuan untuk mencegah tindak kekerasan seksual pada anak (Barliner,2011).

Berdasarkan hasil penelitian yang didapat, yakni total orang tua yang memiliki tingkat pendidikan dasar sebanyak 22 orang tua, 21 orang diantaranya memiliki tingkat pengetahuan kurang, satu orang lainnya memiliki pengetahuan baik. Hal ini menunjukkan bahwa $95 \%$ dari keseluruhan orang tua yang memiliki latar belakang pendidikan formal rendah memiliki tingkat pengetahuan kurang.

Kemudian dari total 46 orang tua yang memiliki tingkat pendidikan menengah, 22 di antaranya memiliki pengetahuan cukup, 12 dengan pengetahuan kurang dan 12 lainnya dengan pengetahuan baik. Hal ini menunjukkan bahwa dari total keseluruhan orang tua yang memiliki latar belakang pendidikan menengah 47,8 \% diantaranya memiliki tingkat pengetahuan cukup. Selanjutnya dari total 16 orang tua yang memiliki tingkat pendidikan tinggi, 15 diantaranya memiliki tingkat pengetahuan baik, dan satu dengan tingkat pengetahuan cukup. Hal ini menunjukkan bahwa 93,8 \% dari keseluruhan ibu yang memiliki latar belakang pendidikan tinggi memiliki pengetahuan yang tinggi.

Berdasarkan hasil penelitian yang telah dipaparkan tersebut dapat dilihat bahwa tingkat pendidikan berbanding lurus degan tingkat pengetahuan orang tua tentang kekerasan seksual pada anak usia prasekolah. Hal ini sejalan dengan penelitian yang dilakukan Suciemilia (2015), Pendidikan orang tua merupakan domain yang sangat penting karena semakin tinggi jenjang pendidikan maka akan memperluas atau mendukung pengetahuan yang diberikan oleh anak dan dengan pendidikan yang baik, orang tua dapat dengan mudah menerima segala informasi dari luar tentang pendidikan seksual.

Namun perlu ditekankan bahwa seseorang dengan pendidikan tinggi belum tidak berarti mutlak berpengetahuan tinggi pula. Dalam penelitian ini didapatkan bahwa terdapat $12(14,3$ $\%)$ responden dengan tingkat pendidikan menengah namun masih berada pada tingkat pengetahuan kurang. Hal ini dapat terjadi karena orang tua masih menganggap tabu membicarakan seks pada anak. Kebanyakan orang tua beranggapan bahwa pendidikan seks hanya berisi tentang pemeberian informasi alat kelamin dan hubungan seks (Lestari dan Prasetyo, 2014). Kesimpang-siuran tentang arti pendidikan seks yang sebenarnya, menjadikan masyarakat memiliki perepsi bahwa pendidikan seks terlalu vulgar apabila diberikan pada anak- 
anak (Justicia,2016). Masyarakat awam cenderung memiliki anggapan bahwa pengetahuan tentang seksual adalah ranah untuk orang dewasa dan anakanak akan mengerti dengan sendirinya saat mereka dewasa.

Pendidikan seks yang diberikan pada anak usia dini akan membuat anak mengetahui batasan mereka sebagai seorang lak-laki dan perempuan (Justicia,2016). Oleh karena itu, anak seharusnya mengetahui batasan tubuh yang boleh dan yang tidak boleh disentuh oleh orang lain atau lawan jenis (Browm,2009), sehingga dengan pendidikan dan pengetahuan seks anak mampu menolak, menghindar, mengadu kepada orang terdekat jika ada seseorang yang melakukan tindakan kejahatan seksual (Rezkisari,2015).

Perlunya pendidikan seks bagi setiap individu tidak hanya bertujuan untuk melindungi diri dari perilaku menyimpang seks, namun juga memahami konsekuensi-konsekuensi sosial akibat perbedaan jenis kelamin tersebut (Justicia,2016). Pendidikan seks yang diberikan haruslah mencakup norma-norma yang ada di masyarakat, yang tidak melanggar aturan0aturan, yang diizinkan di masyarakat dan bagaimana menerapkan di masyarakat tanpa harus mengganggu hak orang lain (Sarwono, 2008).

Orang tua mempunyai fungsi pendidik karena seorang anak pertama kali memperoleh pengetahuan dari orang tua terutama ibu, ayah. Kepribadian seseorang terbentuk dari hasil perpaduan antara warisan sifat-sifat, bakat orang tua dan lingkungan dimana ia berada. Lingkungan pertama yang memberikan pengetahuan mendalam adalah keluarga sendiri (Herjanti,2016).

Selain itu dalam penelitian Wahyuni (2017) menyatakan bahwa semakin tinggi pendidikan orang tua maka tinggi juga pengetahuan orang tua tentang kekerasan pada anak prasekolah. Hal ini sejalan dengan pernyataan Notoatmodjo (2012) bahwa pendidikan dapat membawa wawasan atau pengetahuan seseorang. Secara umum, seseorang yang berpendidikan lebih tinggi akan mempunyai pengetahuan yang lebih luas dibandingkan dengan seseorang yang tingkat pendidikannya lebih rendah.

\section{Kesimpulan}

Berdasarkan hasil penelitian dan pembahasan, maka dapat ditarik simpulan yaitu Ada hubungan antara tingkat pendidikan orang tua dengan pengetahuan tentang kekerasan seksual pada anak usia prasekolah. Hal ini diperoleh dengan uji statistik dan didapatkan $p$ value sebesar 0,000 dan nilai koefisiensi kontingensi sebesar 0,690

\section{Daftar Pustaka}

Barliner. (2011). Child Sexual Abuse: Definition,Prevalence and Consequennces Their Children First Educator About Child Sexual Abuse Prevention Educator. Journal of Populational Health and Health Policy dalamhttps://link.springer.com/article/10.10 80/19361521.2011.545811 diakses tanggal 16 Juni 2018

Brown,John, (2009). The NSPCC Underwear Rule Campaign (Encouraging and Enabling Parants to Talk with Children to Help Keep Them Safe). United Kingdom: NSPCC (Nasional Society for The Prevention of Cruelty to Children) dalam www.nspcc.org.uk diakses tanggal 16 juni 2018.

Cruise, T.K. (2004). Seksual Abuse of Children and Adolescents:Helping Children at Home and School II. Handouts for Families and Educators. Nasional Association of School, Psychologistsdalamhttps://www.questia.com /magazine/1P3-3859273721/sexual-abuseof-children-and-adolescents diakses tanggal 30 Desember 2017

Notoatmodjo, S. (2012). Metode Penelitian Kesehatan, Jakarta: Rineke Cipta.

Notoatmodjo, S. (2012). Promosi Kesehatan dan Perilaku Kesehatan. Jakarta: Rineka Cipta 
Herjanti. (2016). Pola Asuh Orang Tua tentang Pedidikan Seks Anak Usia Dini. Jurnal Ilmu Kebidanan Indonesia. 5(2). 93-106 dalam http://etheses.uinmalang.ac.id/9050/1/13410 164.pdf diakses tanggal 26 Juli 2018

Justicia, Risty. (2016). Program Underwear Rules untuk Mencegah Kekerasan Seksual Pada Anak Usia Dini. Jurnal Pendidikan Anak Usia Dini. 9 (2). 217-232 dalam http://pps.unj.ac.id/journal/jpud/article/view/ 101 diakses tanggal 26 Juli 2018

Komisi Perlindungan Anak Indonesia (KPAI). (2016). Profile dalam http://www.kpai.go.id/profil/ diakses tanggal 1 November 2017

Lestari, Endang \& Prasetyo, Jangkung. (2014). Peran Orang Tua dalam Memberikan Pendidikan Seks Sedini Mungkin Di TK Mardisiwi Desa Kedondong Kecamatan Kebonsari Kabupaten Madiun. NUGROHOJurnal Ilmu Pendidikan. 2(2). 124-131 dalamhttps://www.researchgate.net/publicati on/322794016_EKSPLORASI_PERSEPSI_ IBU_TENTANG_PENDIDIKAN_SEKS_U NTUK_ANAK diakses tanggal 02 Juli 2018

Potter, P., \& Perry, A. (2009). Fundamental keperawatan edisi 7. Jakarta: Salemba Medika

Rezkisari, Indira (2015). KPAI: Pentingnya Pendidikan Seksual Bagi Anak Sejak Usia Dini. www.republika.co.id diakses tanggal 30 Juli 2018

Sari, A. P. (2009) Penyebab Kekerasan Seksual terhadap Anak dan Hubungan Pelaku dengan Korban dalam http://kompas.com/index.php/read/xml/2009 /01/28/ diakses tanggal 27 Oktober 2017

Sarwono, Sarlito. (2008). Psikologi Remaja. Jakarta: Erlangga

Suciemilia. (2015). Identifikasi Peran Orang Tua dalam Memberikan Pendidikan Seksual pada Anak Tunagrahita Di SLBN 1 Bantul Yogyakarta

dalam http://opac.unisayogya.ac.id/id/eprint/174

diakses tanggal 15 Juli 2018

Wahyuni, Siti. (2017). Hubungan Karakteristik Orang Tua dengan Pengetajuan tentang Pencegaham Tindak Kekerasan Seksual pada Anak Usia 3-5 Tahun di KB 'Aisyiyah Rejodani Sariharjo Ngaglik Sleman Bantul.Naskah Publikasi Universitas 'Aisyiyah Yogyakarta Tidak Dipublikasikan.

World Health Organization. Maternal and Child Epidemiology Estimations. (2013). Dalam http://jhsph.edu/departmens/internatinalhealt $\mathrm{h} /$ center-and-institutes/institute-for international program/projects/mcee-childc ause-of-death-estimates.html.

Widyawati,W. (2016). Hubungan Pengetahuan dengan Perilaku Ibu Memberikan Pendidikan Seks pada Anak. Jawa Tengah: Universitas Sebelas Maret 